\title{
The performance effect of network and managerial capabilities of entrepreneurial firms
}

\author{
Marijana Srećković
}

Accepted: 10 January 2017 /Published online: 8 June 2017

(C) The Author(s) 2017. This article is an open access publication

\begin{abstract}
Building on the organizational capabilities view, this study explores the impact of network and managerial capabilities on the performance of entrepreneurial firms in the architecture and real estate sector. We apply an extended organizational capabilities model by integrating Porter's value chain model and Grant's hierarchy of organizational capabilities. Starting from differences in entrepreneurial orientation between architecture and real estate development firms, we argue that under higher environmental uncertainty, network capabilities are more important for the performance of architecture firms whereas managerial capabilities are more important for the performance of real estate development firms. Employing data from Austria, Germany, and Switzerland, the research results support the hypotheses. This study integrates Porter's value chain concept and the organizational capabilities model and delivers a contribution to the organizational capability theory. In addition, it contributes to the entrepreneurship literature by showing that network capabilities are more important for creating competitive advantage in entrepreneurial firms than in other firms.
\end{abstract}

Keywords Organizational capabilities · Coordinative capabilities · Professional service firms · Environmental uncertainty $\cdot$ Entrepreneurial orientation

M. Srećković $(\bowtie)$

Department for Industrial Building and Interdisciplinary Planning, TU Wien, Karlsplatz 13/234-2, 1040 Vienna, Austria e-mail: marijana.sreckovic@tuwien.ac.at
JEL classifications $\mathrm{L} 25 \cdot \mathrm{L} 26 \cdot \mathrm{L} 80 \cdot \mathrm{D} 81 \cdot \mathrm{C} 2$

\section{Introduction}

With the emergence of new organizational forms and environmental dynamism, research on organizational capabilities (OC) and their value creation has become an important focus in the strategic management and entrepreneurship literature. The resource-based and organizational capabilities view argues that firm-specific resources and capabilities result in competitive advantage (Helfat et al. 2007; Jacobides 2006; Teece et al. 1997). If a firm has resources and capabilities, which are rare, difficult to imitate and substitute (Barney 1991), it achieves competitive advantage. In the last 20 years, many authors have contributed to the development of the resource-based theory, in particular, other prominent theoretical contributions have emerged based on early works, the knowledge-based view (Grant 1996), the natural-based view of the firm (Hart 1995), and the dynamic capabilities (Teece and Pisano 1994). The resource-based approach has among others found its way into the field of inter-organizational networks (Lavie 2006) and information systems (Wade and Hulland 2004). OC as high-level routines (Winter 2003) are contributing factors to an efficient production. Embedded in the routines of a firm, they reflect the management system of an organization and are part of the company's culture and the employees' networks. Routines as part of capabilities have the task to coordinate all the skills of the organization. OC are particular 
forms of organizational knowledge (Dosi et al. 2002) or a bundle of potential activities transforming firm's productive resources (Teece 2014), attributing to the organization's ability to create, develop, and provide new products and services.

Dynamic capabilities emphasize the cardinal role of strategic management to appropriately adapt, integrate and reconfigure internal and external organizational skills, resources, and competences in the face of changing environments (Teece and Pisano 1994). Dynamic capabilities provide therefore the ability to perceive and embrace new opportunities and reconfigure assets and competences for the achievement of competitive advantage (Augier and Teece 2009). Nonetheless there is a gap between current conceptual and theoretical studies as well as empirical applications of the capabilities framework (Newbert 2007; Arend and Bromiley 2009; Leiblein 2011; Giudici and Reinmoeller 2012; Grant and Verona 2015). Building on the organizational capabilities view, the aim of this study is to examine the impact of network and managerial capabilities on the performance of entrepreneurial firms in the architecture and real estate sector.

Entrepreneurially oriented organizations have a simultaneous inclination toward product and technological innovation, risk-taking and proactive firm behavior (Miller and Friesen 1983; Covin and Slevin 1989), with numerous studies showing a positive effect between entrepreneurial orientation and firm performance (e.g. Rauch et al. 2009; Wales et al. 2013). The entrepreneurial orientation concept is rooted in the work of Mintzberg (1973) who defined the entrepreneurial strategy-making mode as an active search for opportunities in uncertain environments and Khandwalla's (1977) entrepreneurial management style which comprises bold, risky and aggressive decision-making in industries characterized by intense, diverse, and shifting competitive pressure. Mintzberg (1973) proposes two distinct strategy-making modes of organizations, the entrepreneurial and the adaptive mode. For the purpose of our study we differentiate between the entrepreneurial firm, which is similar to the entrepreneurial organization defined by Mintzberg (1973) and the adaptive firm (Mintzberg 1973). An entrepreneurial strategic posture of a firm is characterized by an active search for opportunities, growth and innovation, whereas in the adaptive mode strategy, the firm is passive, "only" reacting when problem-solving is necessary, deciding in incremental or serial steps (Mintzberg 1973) and innovating reluctantly (Miller and Friesen 1982). Applying this differentiation to SMEs in the architecture and real estate sector, architecture firms are entrepreneurial firms and real estate development firms are adaptive firms.

What are the characteristics of architecture and real estate development firms? They are professional service firms, their work is mainly project-oriented, takes place over significant periods of time (weeks/ months/years), and involves extensive investigation and problem solving, with the aim of serving the external client organization or customer (Stumpf et al. 2002). Architects are in general smaller entrepreneurial firms than real estate developers and are therefore very dependent on their reputation and network relationships to clients for the generation of new business opportunities. Therefore, we expect higher levels of network capabilities to be more important for firm performance of architecture firms than for real estate developers and higher levels of management capabilities to be more important for real estate development firms than for architecture firms for the generation of competitive advantage.

This paper delivers a contribution to the strategic entrepreneurship research in a threefold manner: (1) by developing a novel OC model which extends the Porter (1985) value chain concept and integrates the capability hierarchy from Grant (1995), (2) by testing OC hypotheses in the context of small and medium-sized businesses operating in the architecture and real estate sector, and (3) by showing that, under high environmental uncertainty, network capabilities are more important for the performance of architecture firms, whereas managerial capabilities are more important for the creation of competitive advantage in real estate development firms. To the best of our knowledge, no empirical study so far has analyzed and compared network and managerial capabilities for these types of SMEs.

The paper is organized as follows: First, grounded in the literature of the resource-based view and OC, as well as Porter's value activities and the hierarchy of capabilities from Grant, a research framework for the definition of coordinative capabilities is introduced, which will be further empirically tested. Second, the stepwise regression analysis, sample frame, and results are explained. Finally, we discuss the results and implications of our findings. 


\section{Theoretical framework and hypotheses}

\subsection{An extended organizational capabilities model}

The discussion of the relevant literature shows different concepts of capability hierarchies, which are very heterogeneous (see Table 1). Based on Porter (1985) and Grant (1995, 1996), we argue that the framework of hierarchies of capabilities has to be defined in relation to the specific value chain of the enterprise, as gaps in relevant literature show that the value chain concept has not been integrated in the OC research. Several scholars have proposed capability hierarchies (Collis 1994; Danneels 2002; Winter 2003; Zahra et al. 2006; Ambrosini et al. 2009; Hine et al. 2014; Teece 2014). Building on Winter's work, Nelson (1991) suggests that in successful firms a hierarchy of practiced organizational routines determines organizational skills at the lower level and the way they are coordinated, whereas higher-order decision procedures induce decisions for the lower levels. They represent building blocks of firm's core capabilities. The capability hierarchy of Collis (1994) places the ability to perform the basic functional activities of the firm at the lowest level. His second and third levels comprise the dynamic improvement to the activities of the firm, followed by the last level where innate values of the firm's resources allow the development of novel strategies ahead of the competition. The overview of capability hierarchies, specifically the distinction between dynamic capabilities and other types of OC (first-order, zero-level, substantive, ordinary) defined by different scholars is given in Table 1 , where we relate our hierarchy of capabilities to the typologies presented in literature so far.

Our conceptual research framework integrates the hierarchy of organizational capabilities from Grant $(1995,1996)$ and the value chain framework of Porter (1985), where we extend the existing value chain by adding the level of innovation and entrepreneurship and thereby introducing three levels of corporate activities: the strategic level of corporate activities with dynamic capabilities (innovation and entrepreneurship), the organizational level with coordinative capabilities and the operational level with operational capabilities (Fig. 1).

Porter's value chain framework (Porter 1985, Fig. 1) disaggregates the firm into a sequential chain of value activities, distinguishing between primary activities as those responsible for producing, marketing, and 


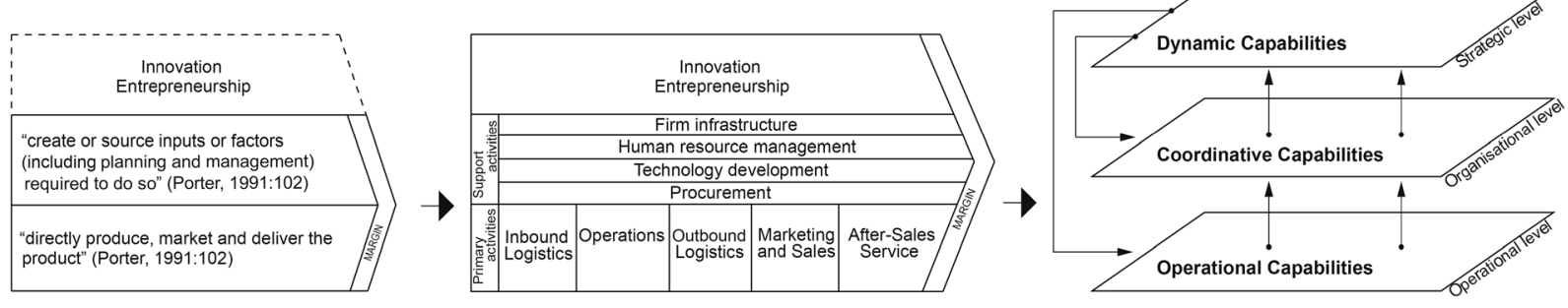

Fig. 1 An extended organizational capabilities model

delivering the product, and support activities defined as those "that create or source inputs or factors (including planning and management) required to do so" (Porter 1991: 102). The primary activities are directly involved in the physical creation of the product, its sale and transfer to the buyer, as well as the after-sale assistance. Support activities are integral to the process by which assets internal to the firm are acquired and accumulated and they support the value creation process of the primary activities by providing purchased inputs, technology, human resources, and various firm-wide functions (Porter 1998). Exploring how each value chain activity is performed and the way it creates value provides the firm with information about its cost position relative to its competitors, as well as necessary sources of buyer value and differentiation. The performance of activities leads to the accumulation of firm's intangible assets, knowledge, routines and skills, which under the circumstances of a relatively stable environment should accumulate over time (Porter 1991). The value creation processes are specific for each industry or organizational typology and they hold the key sources for competitive advantage.

Several scholars (Armistead and Clark 1993; Stabell and Fjeldstad 1998; Løwendahl 2005; Zott and Amit 2013) argue that Porter's value chain framework, while it is well suited to analyze and describe the main value creation process of a generic manufacturing company, is inadequate for many service organizations or professional service firms (i.e., medicine, engineering, architecture, law), as well as new networked organizational forms, which cannot relate to the descriptive terms of the primary activities (inbound logistics, operations, outbound logistics, marketing, and sales) and their sequential character. In reconfiguring his value chain for the operational flow for the delivery of a service, Porter (1998) focuses primarily on cost advantages that can be achieved through more efficient or differentiated primary activities in the new and improved value chain. Nonetheless, in this reconfigured value creation process, the support activities of a firm's infrastructure, technology, human resource management, and procurement are not explored or amended. We close the gap by introducing an extended value chain concept of Porter (1985), with the addition of a third dynamic level (innovation and entrepreneurship) to his original model (Fig. 1). In the Schumpeterian or evolutionary context, a firm must innovate in order to be and stay successful and therefore have capabilities for innovation.

To identify a firm's core (Prahalad and Hamel 1990) or distinctive (Selznick 1957) capabilities, it is necessary to classify its activities, using either a functional classification, where OC pertaining to each activity are defined, or the value chain, where activities follow a sequential order (Grant 1995). Although Porter's (Porter 1985) value chain introduces primary and secondary activities, Grant (1995) suggests that neither a functional nor a value chain approach define OC in a sufficient manner. He uses the term OC "to refer to a firm's capacity for undertaking a particular activity" (Grant 1995:126). In his view, knowledge integration and teams of resources, specifically knowledge and skills of individual employees, comprise the core of OC, establishing herewith his knowledge-based theory of organizational capability (Grant 1996). In complex organizations, capabilities have a hierarchical structure, as some are highly specific and some highly integrative. The integration of the lower-level capabilities into the higher-level is not induced directly but with the support of employees' individual skills and expertise. Grant (1995) refers in his definition of the hierarchy of OC to the value chain of Porter and defines organizational skills at the operational level (OC in the area of procurement, marketing, HRM, etc.), the organizational level ( $\mathrm{OC}$ in the field of organization, decisions, 
communication, and networking), and the strategic level (OC in the field of strategy development and innovation). The definition of organizational and individual capabilities at the operational, organizational and strategic level depends on the type of company (e.g., manufacturing or service) and the respective economic context (market, regulation, etc.) in which the company is operating. We argue that knowledge and resources from the operational, organizational, and strategic level of the firm are bundled and uniquely combined through time and experience to form capabilities that generate and sustain competitive advantage. In this constant process, the company is adapting to the changing market environment, demands, and processes, through innovation and entrepreneurship, which means that the three levels of our capability architecture are "intertwined" in an iterative process of adjusting and improving capabilities and resources (Fig. 1).

In the following, we focus on developing and testing hypotheses on the performance impact of coordinative capabilities (i.e., managerial and network capabilities) of small- and medium-sized businesses operating in the architecture and real estate sector.

\subsection{Empirical framework}

Teece argues that a "firm's distinctive ability needs to be understood as a reflection of distinctive organizational or coordinative capabilities" (Teece et al. 1997: 518). Efficient coordination of activities inside the firm (i.e., internal coordination through managerial capabilities) as well as activities with external partners of the firm (i.e., external coordination through network capabilities) is important for sustained competitive advantage. Ordinary capabilities (Teece 2014) include administration, operation, and governance, which are placed at the operational and organizational level of the firm in our OC model (Fig. 1). Barnard points out "the creative side of organization is coordination" (Barnard 1938: 256). Coordination is the management of task interdependence (Malone and Crowston 1994), which can be interpreted as the way processes in a company are defined, designed, and organized. It includes which configuration of resources the firm can use in manufacturing, distributing, and marketing; its intended products to a targeted market; and the way it deploys resources through organizational structures that support the firm's product strategies (Sanchez 1995). Based on the internal and external focus of coordinative capabilities, we differentiate between managerial capabilities and network capabilities. Figure 2 shows the research framework for our study.

\subsubsection{Coordinative capabilities hypotheses}

Firms are connected in networks of social, professional and exchange relationships (Man et al. 2002). These networks represent an inimitable source of competitive advantage and enable firms to manage resource dependencies, decrease their costs of organizing, and foster knowledge exchange and learning (Baum et al. 2000; Cliquet 2000; Gulati et al. 2000; Windsperger 2004; Goerzen 2007). Resources which are embedded in the entrepreneur's relationship networks involve management skills in terms of the ability to coordinate all these resources (Hernández-Carrión et al. 2017). Top managers of effective entrepreneurial firms are creating and maintaining alliances, developing products, selecting employees (Eisenhardt 2013), and employing top management styles (Covin and Slevin 1989). As such, they are strategic resources for the firm. Managerial behaviors of small entrepreneurial firms promote creativity and risk taking, flat informal structures, and actions toward opportunity exploitation and innovation, whereas non-entrepreneurial managerial behaviors emphasize planning, control, monitoring, evaluation, and formalized organizational structures (Sadler-Smith et al. 2003).

The firm's skills, knowledge, and experience to deal with difficult and complex tasks in management and production (Choi and Shepherd 2004) and the ability to choose activities for the production and delivery of products or services to customers in an efficient and effective manner (Collis 1994) comprise managerial capabilities. These OC are placed at the organizational level of the firm in our OC model (Fig. 1) and refer to the organizational structure and business processes of a firm and the necessary decision procedures (organizational design and decision-making authority; process management). Keegan and Turner (2002) argue that dynamic and uncertain environments prompt changes in terms of how projects are carried out, leading to an increased need for high levels of intra-organizational coordination. Matthews and Scott (1995) argue that increased environmental uncertainty will be associated with decreased level of planning (or coordination) in small entrepreneurial ventures, which might be an adaptive response to a turbulent environment as small firms 


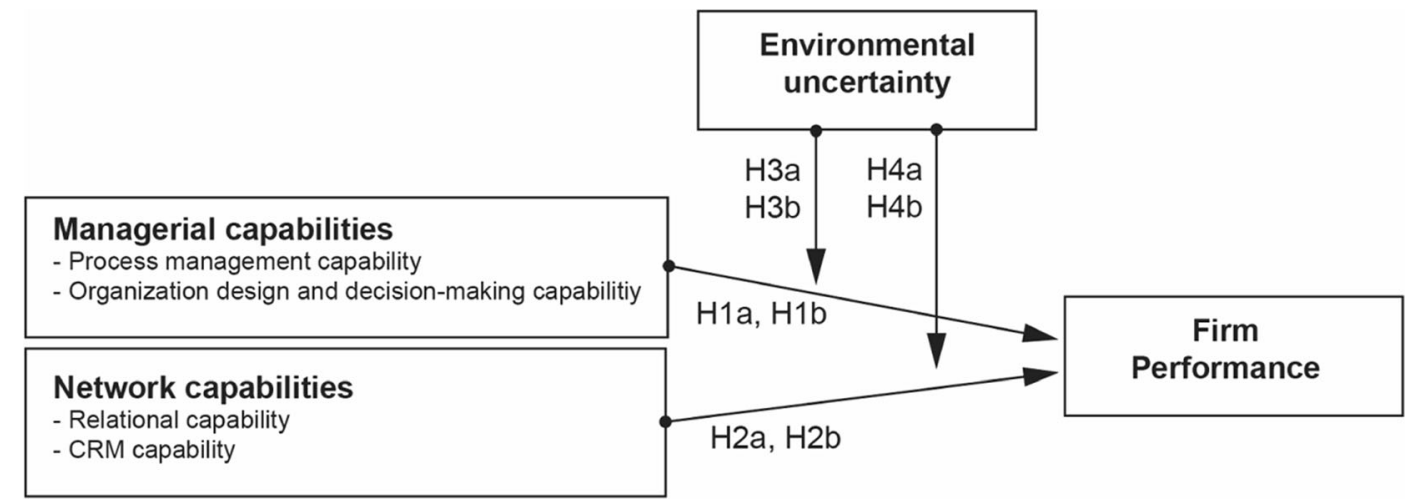

Fig. 2 Empirical framework

are not willing or able to risk time and talent on formal planning due to resource scarcity. For SMEs in the architecture and real estate sector, well-organized tasks and efficient management processes represent crucial factors for the successful completion of building projects. Therefore the hypotheses follow:

Hla: Managerial capabilities have a positive influence on the performance of architecture firms.

$H 1 b$ : Managerial capabilities have a positive influence on the performance of real estate development firms.

The entrepreneur plays an important influential role in affecting the performance of the firm (Man et al. 2002), and even more if the owner and manager of the small business is the same person. In that case, his personal and professional network ties are a valuable resource of competitive advantage for the small firm (Hernández-Carrión et al. 2017) because they enable access to resources created through the network. In addition, network resources are very often heterogeneously disbursed within the same industry, which makes them difficult to imitate (Gulati and Gargiulo 1999; Gulati et al. 2000). Meiseberg and Ehrmann (2012) argue that the decision of the manager to engage in networking is strongly dependent on the firm's alliance capabilities. We argue that the organizational level of the firm incorporates capabilities referring to the coordination and maintenance of inter-organizational networks (see Fig. 1). Network capabilities, also known as social capital (Baron and Markman 2000), external links (Lee et al. 2001), or personal networks (Ostgaard and Birley 1994) refer to the ability to initiate, maintain, and utilize relationships with other partners. Kale et al. (2002) identify four components of the firm's network capability: coordination, relational skills, partner knowledge, and internal communication. In SMEs in the architecture and real estate sector, work is conducted through teams (von Nordenflycht 2010) and networks, where network capabilities, in particular customer relationship management (CRM) capabilities play an important role regarding the maintenance of good client and customers relationships. Based on Morgan et al. (2009) CRM capabilities enable identification of new attractive customers and initiation of new business relationships and help resolve problems with business partners and clients in an efficient and constructive manner. In architecture and real estate development, collaboration with other designers, construction companies, investors, public institutions, and users is a vital part of the business. The relational links in the networks of architecture and real estate development firms, their potential clients and business partners, and other stakeholders in the market are very important for the creation of new ventures and projects. Maintaining, coordinating and utilizing these networks to partners and clients are crucial for successful project completion and for the competitive advantage of these SMEs. Therefore the following hypotheses can be formulated:

H2a: Network capabilities have a positive influence on the performance of architecture firms.

$H 2 b$ : Network capabilities have a positive influence on the performance of real estate development firms.

\subsubsection{Moderating effect of environmental uncertainty}

Environmental dynamism or uncertainty "is characterized by the rate of change and innovation in the industry, as well as the uncertainty or unpredictability of actions of competitors and customers" (Miller and Friesen 1983:222). In uncertain and dynamic environments, 
small firms are facing challenges regarding their access to resources and capabilities (Hernández-Carrión et al. 2017), the available range of strategic and operational planning options (Matthews and Scott 1995), and their level of innovation activities (Acs and Audretsch 1988). The competitiveness of SMEs depends on internal factors, such as "financial, human and technological resources, organizational structures and systems, productivity, innovation, quality, image and reputation, culture, product/service variety and flexibility, and customer service" (Man et al. (2002:129). Regarding external factors, like a hostile or uncertain environment, an entrepreneurial strategic posture is very beneficial for the competitive advantage of the small firm because it will push its competitive efforts (Covin and Slevin 1989).

When the business environment is uncertain, small firms have to change or adapt (Freel 2005) their information processing and structural and decision-making procedures (Miller and Friesen 1982) for growth and innovation. In uncertain environments, entrepreneurs are often faced with information processing burdens (Garrett and Holland 2015) and are therefore making an information-induced effort to reduce uncertainty and risk by establishing personal and professional networks for the exploitation of entrepreneurial opportunities and strategic network resources (such as funding sources, technology, human resources, knowledge, and organizational capabilities). We argue that the impact of managerial and network capabilities on firm performance is contingent on the level of uncertainty in the business environment of entrepreneurial firms. In the context of SMEs in the architecture and real estate sector, environment refers to uncertain and unpredictable changes concerning client and user tastes, technologies (e.g., in design, construction) and services (e.g., in facility management) and the competitive situation.

Coordinative capabilities (i.e., managerial and network capabilities) help firms adapt to uncertain environments through learning and change. Their attribution to a firm's competitive advantage is even more important in turbulent environments than in stable ones (Helfat and Raubitschek 2000; Helfat et al. 2007). Following the arguments from Drnevich and Kriauciunas (2011), who point out the lack of studies on moderating effects of environmental dynamism on ordinary capabilities, we propose that environmental uncertainty will positively moderate the relationship between network and managerial capabilities and performance. In addition, we expect that under high environmental uncertainty network capabilities are more important for the performance of architecture firms and managerial capabilities are more important for the performance of real estate developers. This may be due to differences in entrepreneurial orientation between these two types of SMEs. Therefore, we formulate the following hypotheses:

H3a/H4a: The positive relationship between managerial as well as network capabilities and performance of architecture firms is moderated by environmental uncertainty in such a way that the moderating effect of environmental uncertainty on performance is stronger for network capabilities than for managerial capabilities.

$H 3 b / H 4 b$ : The positive relationship between managerial as well as network capabilities and performance of real estate development firms is moderated by environmental uncertainty in such a way that the moderating effect of environmental uncertainty on performance is stronger for managerial capabilities than for network capabilities.

\section{Method}

\subsection{Data collection}

The empirical data was collected using a self-developed questionnaire for this specific research project. In order to assess the content validity, the survey questions were pretested for relevance and refined in a workshop with eight experts, including CEOs of architecture and real estate development firms and academics familiar with research in the field of strategic management in architecture and real estate. After the workshop, a pilot study was conducted involving five big companies, in order to determine the questionnaire's clarity and phrasing, as well as the layout and completion-time needed. After receiving a positive feedback from the pilot sample members, the same questionnaire was distributed to 216 architecture firms, respectively 242 real estate development firms through postal mail as well as an online survey. The identification of the companies represented in the sample was based on an intensive market research of architecture and real estate development firms with headquarters in Austria, Germany, and Switzerland, as well as companies represented at the internationally renowned real estate fairs Expo Real in Munich, the MIPIM in Cannes and Real Vienna. Our key informants were general managers and chief executive officers as well as firm owners in real estate and architecture 
because they are top decision makers in the company and therefore knowledgeable regarding the issues being researched (Kumar et al. 1993).

The survey was fielded over a period of 4 months. All the members of our survey group received email as well as a letter with the printout of the questionnaire by regular mail, with a survey invitation and the explanation of the background and purpose of the research (Dilman 2000). All responses were collected with the premise of anonymity, in order to keep the answers as accurate and honest as possible. Measures were taken to ensure a high response rate, as respondents were able to respond and return the survey by regular mail, facsimile, or email. We offered our survey participants also the report of our findings. Finally, we used also personalized email reminders and called the companies by phone in order to assure the participation of all our chosen companies in the survey.

We examined the non-response bias by investigating whether the results obtained from the analysis were driven by differences between the group of respondents and the group of non-respondents. Non-response bias was estimated by comparing early versus late respondents (Armstrong and Overton 1977) where late respondents serve as proxies for non-respondents. Our $t$ tests for differences between these two groups showed no statistical significance in the survey items used in the study. In addition, based on Podsakoff et al. (2003), we checked for common method bias by applying Harman's single-factor test. Neither common method bias nor single-respondent bias could be corroborated.

\subsection{Sample composition}

On the property markets in Austria, Germany, and Switzerland, a relatively large number of real estate development firms are active. This implies a correspondingly high rivalry among competitors in terms of available land, the required investment capital, and the potential tenants and owners of properties. The same competitive situation applies to Austrian, Swiss, and German architecture firms, who are all active in these three countries. Because of the similarities in regulation and real estate development phases as well as similar design and construction processes between these three countries, and the fact that all respondents of our empirical studies are operating in Austria, Germany, and Switzerland, firms from these countries have been selected for the empirical research. The export of project development services and architectural services requires in-depth knowledge of the existing competition in the relevant markets, the country's culture, legal and institutional framework, which makes local partners obligatory and well-established networks necessary for successful project completion. An overwhelming majority of the respondents (architecture and real estate development firms) are active in foreign markets. In addition it has to be mentioned that we have chosen to compare SMEs from the architecture and real estate sector as they are relevant stakeholders in building projects and one depends on the other for the provision of commissions, investments, or services. The classification into SMEs was based on the European Commission's definition regarding the number of employees (500 max.), revenue per year ( $€ 50$ Mill. max.) and balance sheet total [2003/361 (EUR-Lex - 32003H0361)] (Tables 2 and 3). In general, architecture firms are smaller businesses than real estate development firms and have therefore a lower average turnover, which is also supported in our sample description.

Table 2 Sample composition for architecture firms

\begin{tabular}{lll}
\hline $\begin{array}{l}\text { Firm employees: number of } \\
\text { full-time equivalents }\end{array}$ & $\begin{array}{l}\text { Percentage } \\
(\%)\end{array}$ & $\begin{array}{l}\text { Cumulative } \\
\text { percentage }(\%)\end{array}$ \\
\hline$<5$ & 6.3 & 6.3 \\
$5-15$ & 26.6 & 32.9 \\
$16-30$ & 19.0 & 51.9 \\
$31-50$ & 17.7 & 69.6 \\
$>50$ & 30.4 & 100
\end{tabular}

Firms age: years since foundation

$\begin{array}{lll}<3 & 1.27 & 1.27\end{array}$

$\begin{array}{lll}3-5 & 1.27 & 2.54\end{array}$

$\begin{array}{lll}5-10 & 15.19 & 17.73\end{array}$

$\begin{array}{lll}10-20 & 34.18 & 51.91\end{array}$

$\begin{array}{lll}>20 & 48.1 & 100\end{array}$

Annual turnover (in 2009)

$\begin{array}{lll}<0.5 \text { Mill } € & 5.06 & 5.06 \\ 0.5-1.5 \text { Mill } € & 25.32 & 30.38 \\ 1.5-3 \text { Mill } € & 20.25 & 50.63 \\ 3-5 \text { Mill } € & 18.99 & 69.62 \\ >5 \text { Mill } € & 30.38 & 100\end{array}$


Table 3 Sample composition for real estate development companies

\begin{tabular}{lll}
\hline $\begin{array}{l}\text { Firm employees: number of } \\
\text { full-time equivalents }\end{array}$ & $\begin{array}{l}\text { Percentage } \\
(\%)\end{array}$ & $\begin{array}{l}\text { Cumulative } \\
\text { percentage }(\%)\end{array}$ \\
\hline$<5$ & 5.2 & 5.2 \\
$5-15$ & 19.6 & 24.8 \\
$16-30$ & 19.6 & 44.4 \\
$31-50$ & 3.1 & 47.4 \\
$>50$ & 52.5 & 100
\end{tabular}

Firms age: years since foundation

$\begin{array}{lll}<3 & 3.1 & 3.1 \\ 3-5 & 7.2 & 10.3 \\ 5-10 & 18.6 & 28.9 \\ 10-20 & 40.2 & 69.1 \\ >20 & 30.9 & 100\end{array}$

Annual turnover (in 2009)

$\begin{array}{lll}<10 \text { Mill } € & 15.5 & 15.5 \\ 10-50 \text { Mill } € & 20.6 & 36.1 \\ 50-100 \text { Mill } € & 11.3 & 47.4 \\ >100 \text { Mill } € & 52.6 & 100\end{array}$

\subsubsection{Architecture firms}

Out of the 216 selected architecture firms, 101 were from Austria, 85 from Germany, and 30 from Switzerland. Finally, 79 completed responses were collected-among those were 40 architecture companies from Austria, 28 from Germany, and 11 from Switzerland - which amounts to a response rate of $37 \%$. The sample composition shows $30 \%$ of companies which have more than 50 employees, $48 \%$ of companies are more than 20 years old, and more than $30 \%$ of the respondents have had more than 5 million Euros annual turnover in 2009 (Table 2). All of the participating architecture companies from Austria, Switzerland, and Germany are working internationally and have projects in several markets: $37 \%$ projects in Central Europe, $13 \%$ in South Eastern Europe, $17 \%$ in Eastern Europe, $8 \%$ in South Europe, 7\% in Western Europe, $4 \%$ in North Europe, and 14\% in other countries.

\subsubsection{Real estate development firms}

Out of the 242 selected real estate development firms, 102 were from Austria, 114 from Germany and 26 from Switzerland. After the completion of the inquiry process, 97 completed questionnaires were collectedthe sample consisted of 49 real estate development firms from Austria, 37 from Germany, and 11 from Switzerland-which amounts to a response rate of $40 \%$. The sample composition shows that more than $50 \%$ of the interviewed companies have more than 50 employees, $40 \%$ of companies are between 10 and 20 years old, and more than $50 \%$ of the respondents have had more than 100 million Euros annual turnover in 2009 (Table 3). All of the participating real estate development companies from Austria, Switzerland, and Germany are working internationally and have projects in several markets: 41\% projects in Central Europe, $15 \%$ in South Eastern Europe, 26\% in Eastern Europe, $8 \%$ in South Europe, $5 \%$ in Western Europe, $4 \%$ in North Europe, and 5\% in other countries.

\subsection{Measurement}

The measures of dependent and independent variables are summarized in the Appendix.

\subsubsection{Dependent variable}

Firm performance (PERF) It is commonly seen as a multi-dimensional construct (Chakravarthy 1986, Morgan et al. 2004) and in this study, it was operationalized and aggregated as a mean of two distinctive dimensions: market performance indicators and financial performance indicators - which were subsequently identified out of six items using factor analysis. We asked our responding CEOs to evaluate their businessperformance relative to their main competitors on the market (Day and Nedungadi 1994) on a 7-point Likert scale (ranging from $1=$ "does not apply at all" through 4 $=$ "applies partially" to $7=$ "applies completely"). Market performance was measured with the dimensions: attractiveness for employees, brand awareness/reputation, and customer loyalty (Cronbach's alpha: architects $=0.734 /$ real estate development firms $=0.722$ ), whereas firm performance was measured with the items: sales growth, profitability, and market position/increase in market share (Cronbach alpha architects $=0.712 /$ real estate development firms $=0.701$ ).

\subsubsection{Predictor variables}

$\mathrm{OC}$ were measured as formative indicators. Concerning the measurement of items, it has to be emphasized that 
no operationalization of $\mathrm{OC}$ in the architecture and real estate sector has been done so far. The OC used in our study have been defined in accordance with the input from a workshop of experts from the sector and in a second step confirmed with an independent group of professionals working in top management positions. CEOs of our selected companies in the data sample were asked to evaluate their competitive advantage regarding managerial capabilities (MC) [process management capability, organization design and decision-making capability] and network capabilities (NC) [relational capability, customer relationship management capability].

Environmental uncertainty (EU) was measured with three items, based on Miller and Dröge (1986) and Miller and Friesen (1983), using the 7-point Likert scale $($ Cronbach's alpha $=0.799)($ see Table 8$)$.

\subsubsection{Control variables}

The control variables firm age (AGE), size (FT), and competition intensity (COMP) were included in the conceptual framework. In the context of competitiveness of architecture and real estate development firms, the firms' age is relevant due to the fact that older firms presumably have more experience and a larger network of clients and partner firms. Age was calculated as the number of years since their foundation. Firm size was operationalized with annual firm turnover (FT) to establish if the company is a small or medium-sized enterprise. The construction and real estate market is highly competitive and therefore the intensity of competition, according to Porter (2008), was used as a control variable.

\section{Results}

The descriptive statistics and correlations are presented in Tables 4 and 5. The variance inflation factor was calculated for all regressions in the conceptual framework in order to test for multicollinearity. All VIF values are lower than 5 (Diamantopoulos and Riefler 2008) this points to the fact that there is no multicollinearity concern. All independent and control variables are mean-centered, as to prevent any multicollinearity issues as well.

To test the proposed research framework, we employ hierarchical ordinary least squares regression (OLS) analysis (Aiken and West 1991). We propose the following regression equation for the empirical test for architecture firms and for real estate development firms:

$$
\begin{aligned}
\mathrm{PERF}_{\text {Architecture }}= & \beta_{0}+\beta_{1} \mathrm{AGE}+\beta_{2} \mathrm{FT}+\beta_{3} \mathrm{COMP} \\
& +\beta_{4} \mathrm{MC}+\beta_{5} \mathrm{NC}+\beta_{6} \mathrm{EU}+\beta_{7} \mathrm{MC} \\
& \times \mathrm{EU}+\beta_{8} \mathrm{NC} \times \mathrm{EU}+\varepsilon
\end{aligned}
$$

$$
\begin{aligned}
\mathrm{PERF}_{\text {Real estate }}= & \beta_{0}+\beta_{1} \mathrm{AGE}+\beta_{2} \mathrm{FT}+\beta_{3} \mathrm{COMP} \\
& +\beta_{4} \mathrm{MC}+\beta_{5} \mathrm{NC}+\beta_{6} \mathrm{EU}+\beta_{7} \mathrm{MC} \\
& \times \mathrm{EU}+\beta_{8} \mathrm{NC} \times \mathrm{EU}+\varepsilon
\end{aligned}
$$

The results of the regression analysis are shown in Table 6 and Table 7.

In this study, we hypothesized that coordinative capabilities, consisting of managerial and network capabilities, have a positive influence on the performance of SMEs in the architecture (H1a, H2a) and real estate sector (H1b, H2b). Our results provide strong support for $\mathrm{H} 1$ and $\mathrm{H} 2$. In addition, we argued that environmental uncertainty positively moderates the performance effect of managerial and network capabilities, while we hypothesized that, under high environmental uncertainty, network capabilities are more important for the performance of architecture firms and managerial capabilities are more important for the performance of real estate development firms. The results of the regression analysis show that environmental uncertainty does not moderate the impact of managerial capabilities on performance (H3a) of architecture firms, but it positively moderates the impact of network capabilities (H4a) on firm performance. Regarding real estate development firms, the results indicate that environmental uncertainty only slightly moderates the impact of managerial capabilities on firm performance (H3b) and has no impact on the relationship between network capabilities and performance $(\mathrm{H} 4 \mathrm{~b})$. In addition the size of the firm has positive impact on firm performance for both architecture and real estate development firms, whereas age only shows a significant positive influence on the performance of real estate development firms.

\section{Discussion and implications}

This study explores the effect of coordinative (managerial and network) capabilities on the performance of small and medium-sized firms operating under 
Table 4 Descriptive statistics for architecture firms

\begin{tabular}{|c|c|c|c|c|c|c|c|c|c|c|c|}
\hline Full sample $(N=79)$ & Min & Max & Ave & SD & 1 & 2 & 3 & 4 & 5 & 6 & 7 \\
\hline 1. Firm performance (PERF) & 2.5 & 6.17 & 4.590 & 0.804 & 1 & & & & & & \\
\hline 2. Age (AGE) & 1 & 5 & 4.265 & 0.858 & $0.241 *$ & 1 & & & & & \\
\hline 3. Firm turnover $(\mathrm{FT})$ & 1 & 5 & 3.443 & 1.298 & $0.433 * *$ & $0.535 * *$ & 1 & & & & \\
\hline 4. Competition (COMP) & 2.5 & 7 & 5.247 & 1.160 & -0.166 & -0.141 & $-0.275^{*}$ & 1 & & & \\
\hline 5. Managerial capabilities (MC) & 1.5 & 7 & 4.696 & 1.360 & $0.376 * *$ & $0.323 * *$ & $0.422 * *$ & 0.014 & 1 & & \\
\hline 6. Network capabilities (NC) & 1 & 7 & 5.228 & 1.204 & $0.519 * *$ & -0.019 & 0.172 & -0.054 & 0.000 & 1 & \\
\hline 7. Environmental uncertainty (EU) & 2 & 7 & 4.561 & 1.083 & -0.183 & -0.013 & 0.087 & -0.108 & -0.026 & -0.052 & 1 \\
\hline
\end{tabular}

* Correlation is significant at the 0.05 level (2-tailed)

**Correlation is significant at the 0.01 level (2-tailed)

environmental uncertainty in the architecture and real estate sector in Austria, Germany, and Switzerland. In our extended OC model (Fig. 1) coordinative capabilities are placed at the organizational level of the firm. The attribution of coordinative capabilities to a firm's competitive advantage is even more important in turbulent environments than in stable ones (Helfat and Raubitschek 2000; Helfat et al. 2007), because they help firms adapt to uncertain environments through learning and change. Based on Mintzberg's view (Mintzberg 1973), we differentiate between entrepreneurial and adaptive firms whereby the entrepreneurial firm is characterized by an active search for opportunities, growth, and innovation, while an adaptive firm is more risk-averse, less innovative, and reactive (Covin and Slevin 1989) under high environmental uncertainty.

Architecture firms as entrepreneurial firms are small businesses of the creative industries (Chaston and Sadler-Smith, 2012) and very dependent on their reputation and network relationships to business partners and clients for the generation of new business opportunities. Intensive interdisciplinary cooperation, strong networking, and diversity of stakeholders participating in the planning and development process of a project are the main business characteristics of these entrepreneurial firms. Involved in long-term creative projects, they practice a management style with "intuition, informality and speed of decision making" (Powell 2008, p. 158), which corresponds to the entrepreneurial strategymaking mode of the firm (Mintzberg 1973). What makes them entrepreneurial is also the fact that they are usually very small business with flat organizational structures and a small management team, where the owner/entrepreneur/manager is one and the same person, building alliances (personal and professional networks) and looking for new opportunities for growth. Managerial behaviors of small entrepreneurial firms promote creativity and risk taking, flat informal structures, and actions toward opportunity exploitation and innovation, whereas managerial behaviors of nonentrepreneurial firm emphasize planning, control,

Table 5 Descriptive statistics for real estate development firms

\begin{tabular}{|c|c|c|c|c|c|c|c|c|c|c|c|}
\hline Full sample $(N=97)$ & Min & Max & Ave & SD & 1 & 2 & 3 & 4 & 5 & 6 & 7 \\
\hline 1. Firm performance (PERF) & 2.67 & 7 & 4.780 & 0.899 & 1 & & & & & & \\
\hline 2. Age (AGE) & 1 & 5 & 3.845 & 1.064 & $0.324 * *$ & 1 & & & & & \\
\hline 3. Firm turnover $(\mathrm{FT})$ & 1 & 4 & 3.010 & 1.168 & $0.244 *$ & $0.220 *$ & 1 & & & & \\
\hline 4. Competition (COMP) & 1.5 & 7 & 4.186 & 1.213 & 0.069 & 0.115 & 0.048 & 1 & & & \\
\hline 5. Managerial capabilities (MC) & 3 & 7 & 5.639 & 0.932 & 0.153 & -0.127 & -0.175 & 0.014 & 1 & & \\
\hline 6. Network capabilities (NC) & 1.5 & 7 & 5.072 & 1.218 & $0.473 * *$ & 0.106 & -0.094 & -0.054 & 0.000 & 1 & \\
\hline 7. Environmental uncertainty (EU) & 1 & 7 & 4.213 & 1.246 & -0.178 & -0.059 & 0.094 & -0.108 & $-0.231 *$ & -0.071 & 1 \\
\hline
\end{tabular}

*Correlation is significant at the 0.05 level (2-tailed)

**Correlation is significant at the 0.01 level (2-tailed) 
Table 6 Hierarchical regression analysis on firm performance of architecture firms with OC

\begin{tabular}{|c|c|c|c|c|c|c|}
\hline Variables & Coefficient & SE & Coefficient & SE & Coefficient & SE \\
\hline (Constant) & $6.017 * * *$ & $(1.459)$ & $7.592 * * *$ & $(1.246)$ & $7.397 * * *$ & $(1.208)$ \\
\hline Firm age (AGE) & 0.013 & $(2.377)$ & 0.032 & $(1.930)$ & 0.000 & $(1.871)$ \\
\hline Firm turnover (FT) & $0.412 * * *$ & $(1.463)$ & $0.185^{*}$ & $(1.284)$ & $0.225 * *$ & $(1.252)$ \\
\hline Competition (COMP) & -0.051 & $(0.174)$ & $-0.156^{*}$ & $(0.143)$ & -0.126 & $(0.139)$ \\
\hline Managerial capabilities (MC) & & & $0.292 * * *$ & $(0.152)$ & $0.239 * *$ & $(0.150)$ \\
\hline Network capabilities (NC) & & & $0.476 * * *$ & $(0.137)$ & $0.469 * * *$ & $(0.134)$ \\
\hline Environmental uncertainty (EU) & & & $-0.194 * *$ & $(0.136)$ & $-0.216^{* *}$ & $(0.138)$ \\
\hline $\mathrm{MC} \times \mathrm{EU}$ & & & & & 0.047 & $(0.141)$ \\
\hline $\mathrm{NC} \times \mathrm{EU}$ & & & & & $0.221 * * *$ & $(0.137)$ \\
\hline$n$ & 79 & & 79 & & 79 & \\
\hline$F$ statistic & 5.876 & & 12.301 & & 10.935 & \\
\hline$R^{2}$ & 0.190 & & 0.506 & & 0.555 & \\
\hline Adjusted $R^{2}$ & 0.158 & & 0.465 & & 0.505 & \\
\hline Change in $R^{2}$ & & & 0.316 & & 0.049 & \\
\hline F statistic for change in $R^{2}$ & & & $15.353^{* * * *}$ & & $3.882 * *$ & \\
\hline Mean VIF & 1.3 & & 1.3 & & 1.3 & \\
\hline
\end{tabular}

$* p<0.1 *, * * p<0.05, * * * p<0.01$

monitoring, evaluation, and formalized organizational structures (Sadler-Smith et al. 2003).

Real estate development firms are adaptive firms (Mintzberg 1973). Their business is project- or program-oriented and takes extensive investigation and problem solving, with the aim of serving the external client organization or customer (Stumpf et al. 2002). In order to finance, lease, or sell, real estate development

Table 7 Hierarchical regression analysis on firm performance of real estate development firms with OC

\begin{tabular}{|c|c|c|c|c|c|c|}
\hline Variables & Coefficient & SE & Coefficient & SE & Coefficient & SE \\
\hline (Constant) & $0.835 * * *$ & $(0.049)$ & $0.829 * * *$ & $(0.042)$ & $0.834 * * *$ & $(0.042)$ \\
\hline Firm age (AGE) & $0.280 * * *$ & $(0.067)$ & $0.227 * * *$ & $(0.057)$ & $0.228 * * *$ & $(0.057)$ \\
\hline Firm turnover (FT) & $0.181 *$ & $(0.051)$ & $0.282 * * *$ & $(0.044)$ & $0.273 * * *$ & $(0.044)$ \\
\hline Competition (COMP) & 0.028 & $(0.007)$ & 0.041 & $(0.006)$ & 0.050 & $(0.006)$ \\
\hline Managerial capabilities (MC) & & & $0.206^{* *}$ & $(0.007)$ & $0.195 * *$ & $(0.007)$ \\
\hline Network capabilities (NC) & & & $0.470 * * *$ & & $0.488 * * *$ & $(0.006)$ \\
\hline Environmental uncertainty (EU) & & & -0.106 & & $-0.150 *$ & $(0.007)$ \\
\hline $\mathrm{MC} \times \mathrm{EU}$ & & & & & $0.144 *$ & $(0.006)$ \\
\hline $\mathrm{NC} \times \mathrm{EU}$ & & & & & 0.048 & $(0.008)$ \\
\hline$n$ & 97 & & 97 & & 97 & \\
\hline$F$ statistic & 4.912 & & 10.741 & & 8.470 & \\
\hline$R^{2}$ & 0.137 & & 0.417 & & 0.435 & \\
\hline Adjusted $R^{2}$ & 0.109 & & 0.378 & & 0.384 & \\
\hline Change in $R^{2}$ & & & 0.280 & & 0.018 & \\
\hline F statistic for change in $R^{2}$ & & & $14.440 * * *$ & & 1.384 & \\
\hline Mean VIF & 1.1 & & 1 & & 1.2 & \\
\hline
\end{tabular}

$* p<0.1, * * p<0.05, * * * p<0.01$ 
firms must engage the services of many other experts, public and private (architects, construction companies, facility managers, agents, financiers) and therefore they need structured and formal procedures for collaboration. Small and medium companies in the real estate sector employ formalized and structured management processes for the exploration of opportunities and growth (Charney 2001) and show a more risk-averse and less innovative behavior under environmental uncertainty, which makes them similar to the adaptive firm (Mintzberg 1973).

Consistent with our hypotheses, managerial capabilities have a significant and positive effect on firm performance of architecture and real estate development firms. This suggests that managerial capabilities (i.e. process management, organization design and decision-making capabilities) are non-imitable OC that generate competitive advantage, because of high requirements regarding the management process of the building project from day one through the completion of the design resp. development process. Real estate development and architecture firms are project-based organizations; therefore, efficient and well-organized management processes are cardinal for successful project completion.

In addition, consistent with the hypotheses, we find support for the positive impact of network capabilities on firm performance. The strong positive influence of network capabilities on performance for real estate developers and architecture firms suggests that strong inter-firm networks as well as communication capabilities play an important role in the achievement of competitive advantage. The results show that network capabilities are of great significance for entrepreneurial firms. They include relationships with business partners, authorities, customers or clients, potential users, consultants, and many more. In the complex and dynamic environment, networks are becoming increasingly important and exceed very often geographical, cultural, and political borders, especially in international projects. The capability to manage networks (Gulati et al. 2000) is intertwined and connected with the organization design and process management capability. Therefore, the results of the study suggest that OC (such as managerial and network capabilities), which enable the company to successfully communicate with its stakeholders and partners as well as to build internal and external networks, lead to competitive advantage.
Furthermore, the results of our study indicate that environmental uncertainty positively moderates the influence of managerial capabilities on performance of real estate development firms, whereas it does not moderate the influence of managerial capabilities on performance of architecture firms. What is the explanation? We argue that real estate development firms show a less entrepreneurial strategic posture and therefore have more formal organizational processes for information processing and decision-making. Keegan and Turner (2002) argue that dynamic and uncertain environments prompt changes in terms of how projects are carried out, leading to an increased need for high levels of intra-organizational coordination which is confirmed in regard to real estate development firms but not in the case of architecture firms. Small entrepreneurial firms, such as architecture firms, react to the inability to predict or understand the environment, due to the lack of information, with less sophisticated strategic planning (Matthews and Scott 1995), and involve less time and resources in intra-firm coordination. Our analysis implies that architecture firms can strengthen their competitive advantage under high environmental uncertainty by developing network capabilities. This may be due to the fact that architects, who mostly operate in small businesses, are much more dependent on their invisible assets (Itami and Roehl 1987), such as reputation and brand (Uzzi 1996) as well as experience and networks of contacts to loyal clients which they have developed over the years (Løwendahl 2014). They need to initiate and maintain close relationships with their clients in order to acquire new projects and remain competitive in highly uncertain markets.

For both architects and real estate developers, firm size (firm turnover) has a significant effect on firm performance. Architecture firms have to finance their participation in open competitions in advance in order to win an architectural commission, which means that if they are not successful the high initial investment (e.g., man hours, equipment) can jeopardize the firm's existence and competitiveness on the market. Real estate developers are also investing in building projects in advance depending on the type of developer. In this case, the age of the company has a significant impact on performance because older firms are more capable of mitigating unsuccessful investments, for instance due to accumulated financial resources. 
This paper contributes to the strategic entrepreneurship research with the development of a novel OC model. Our OC model extends the Porter (1985) value chain concept and integrates the capability hierarchy of Grant (1995). Furthermore, we derive and test hypotheses in the context of SMEs as entrepreneurial firms operating in the architecture and real estate sector. To the best of our knowledge, no previous study has analyzed the impact of OC (managerial and network capabilities) on the performance of SMEs in the architecture and real estate industry. The findings indicate that network capabilities are more important for the performance of architecture firms under high environmental uncertainty and managerial capabilities are more important for the performance of real estate firms under high environmental uncertainty. The results of our study suggest that this is due to the fact that entrepreneurial orientation of architecture firms relative to real estate development firms is more important for firm performance in highly uncertain business environments. In conclusion, small entrepreneurial firms can benefit from the development of network capabilities respectively resources embedded in the professional and personal network of the entrepreneur.

This study offers the following managerial implications for small entrepreneurial firms: The specific network structure, the membership in the network, the way in which the company is integrated into the network (e.g., through personal connections, technology, interfaces, organizational structures, etc.) and the company's ability to connect with business partners in this network are non-imitable sources of competitive advantage. Therefore, entrepreneurial firms, which are dependent on networks to receive a mandate or accept a bid, should strategically develop network capabilities in order to stay competitive. The development of flexible and quickly adaptable management processes and organizational structures is cardinal. Especially in a project setting, where unexpected coordination problems (concerning design and construction time frames, quality, quantity, or costs of a building project among others) frequently occur, coordination capabilities, such as managerial and network capabilities, represent an inimitable source of competitive advantage for these SMEs.

Acknowledgements Open Access funding provided by TU Wien (TUW).

\section{Appendix}

Table 8 Measures and items

Construct/variable Cronbach's alpha

- Firm performance (PERF)

Relative to our major competitors our business-performance is very good with respect to:[7-point Likert scale, ranging from 1 = "does not apply at all" through 4 = "applies partially" to 7 = "applies completely"; adapted from Homburg and Pflesser (2000), Homburg et al. (2010), Vorhies and Morgan (2005), Morgan et al.

(2009), Brouthers and Nakos (2004)]

Market performance

1. Attractiveness for employees

2. Brand awareness /reputation

3. Customer loyalty

Financial performance

1. Sales growth

2. Profitability

3. Market position/increase in market share

- Age (AGE)

Log of the number of years since founding

- Firm turnover (FT)

Firm size was measured with annual turnover:

(a) For real estate developers: please indicate how much turnover has your company generated in the year 2009 (in Mill. Euro: <10, 10-50, 50-100, $>100$ )

(b) Architects: please indicate how much turnover has your company generated in the year 2009 (in Mill. Euro: $<0.5,0.5-1.5,1.5-3,3-5,>5$ )

- Competition (COMP)

Please rate your target market or the market for your strongest business unit:

[7-point Likert scale, ranging from $1=$ "does not apply at all" through 4 = "applies partially" to $7=$ "applies completely"; adapted from Porter (2008)]

1. New competitors enter the market very frequently

2. The competition is highly intensive

- Environmental uncertainty (EU)

Please rate your target market or the market for your strongest business unit:

[7-point Likert scale, ranging from $1=$ "does not apply at all" through $\alpha=0.734$ architect.

$\alpha=0.722 /$ real est.

$\alpha=0.712 /$ architect.

$\alpha=0.701 /$ real est.

$\alpha=0.701 /$ architect.

$\alpha=0.723 /$ real est.

$\alpha=0.799 /$ architect.

$\alpha=0.690 /$ real est. 
Table 8 (continued)

Construct/variable

Cronbach's alpha

4 = "applies partially" to 7 = "applies

completely"; adapted from: Miller

and Dröge (1986), Miller and Friesen

(1983)]

1. The market environment is changing very rapidly

2. Demand and tastes are unpredictable

3. The prices of products/services change frequently

- Managerial capabilities (MC)

Please rate your competitive advantage in the following areas:

[7-point Likert scale, ranging from

$1=$ "we have no competitive advantage" through 4 = "we have partial competitive advantage" to 7 = "we have a large competitive advantage]

Process management capability (defining and coordinating processes, exploiting resources and tasks)

Organization design and decisionmaking capability (supervision, delegation, organizing, and motivating employees)

- Network capabilities (NC)

Please rate your competitive advantage in the following areas:

[7-point Likert scale, ranging from $1=$ "we have no competitive advantage" through 4 = "we have partial competitive advantage" to 7 = "we have a large competitive advantage]

Relational capability (initiate, build and utilize networks, foster relationships with network partners)

Customer relationship management capability (identify new attractive customers and initiate new business relationships, resolve problems with business partners and clients in an efficient and constructive manner)

Open Access This article is distributed under the terms of the Creative Commons Attribution 4.0 International License (http:// creativecommons.org/licenses/by/4.0/), which permits unrestricted use, distribution, and reproduction in any medium, provided you give appropriate credit to the original author(s) and the source, provide a link to the Creative Commons license, and indicate if changes were made.

\section{References}

Acs, Z. J., \& Audretsch, D. B. (1988). Innovation in large and small firms: an empirical analysis. The American Economic Review, 78(4), 678-690.

Aiken, L. S., \& West, S. G. (1991). Multiple regression: testing and interpreting interactions. Newbury Park, CA: Sage.

Ambrosini, V., Bowman, C., \& Collier, N. (2009). Dynamic capabilities: an exploration of how firms renew their resource base. British Journal of Management, 20, 9-24. doi:10.1016 /j.emj.2007.05.001.

Arend, R. J., \& Bromiley, P. (2009). Assessing the dynamic capabilities view: spare change, everyone? Strategic Organization, 7(1), 75-90. doi:10.1177/1476127008100132.

Armistead, S. G., \& Clark, G. (1993). Resource activity mapping: The value chain in service operations strategy. The Service Industries Journal, 13(4), 221. doi:10.1080/02642069300000070.

Armstrong, J. S., \& Overton, T. S. (1977). Estimating nonresponse bias in mail surveys. Journal of Marketing Research, 35(8), 396-402. doi: $10.2307 / 3150783$.

Augier, M., \& Teece, D. (2009). Dynamic capabilities and the role of managers in business strategy and economic performance. Organization Science, 20(2), 410. doi:10.1287/orsc.1090.0424.

Barnard, C. I. (1938). The functions of the executive. Cambridge, MA: Harvard University Press.

Barney, J. (1991). Firm resources and sustained competitive advantage. Journal of Management, 17(1), 99. doi:10.1177 /014920639101700108.

Baron, R. A., \& Markman, G. D. (2000). Beyond social capital: how social skills can enhance entrepreneurs' success. The Academy of Management Executive, 14(1), 106-116. doi:10.1016/S0883-9026(00)00069-0.

Baum, J. A. C., Calabrese, T., \& Silverman, B. S. (2000). Don't go it alone - alliance network composition and startups' performance in Canadian biotechnology. Strategic Management Journal, 21(3), 267-294. doi:10.1002/(SICI)1097-0266 (200003)21:3<267::AID-SMJ89>3.0.CO;2-8.

Brouthers, K. D., \& Nakos, G. (2004). Sme entry mode choice and performance: a transaction cost perspective. Entrepreneurship Theory and Practice, 28(3), 229-247. doi:10.1111/j.1540-6520.2004.00041.x.

Chakravarthy, B. S. (1986). Measuring strategic performance. Strategic Management Journal, 7(5), 437-458. doi:10.1002 /smj.4250070505.

Charney, I. (2001). Three dimensions of capital switching within the real estate sector: a Canadian case study. International Journal of Urban and Regional Research, 25(4), 740-758. doi:10.1111/1468-2427.00342.

Chaston, I., \& Sadler-Smith, E. (2012). Entrepreneurial cognition, entrepreneurial orientation and firm capability in the creative industries. British Journal of Management, 23(3), 415-432. doi: 10.1111/j.1467-8551.2011.00752.x.

Choi, Y. R., \& Shepherd, D. A. (2004). Entrepreneurs' decisions to exploit opportunities. Journal of Management, 30, 377-395. doi:10.1016/j.jm.2003.04.002.

Cliquet, G. (2000). Plural forms in store networks: a model for store network evolution. International Review of Retail, Distribution and Consumer Research, 10, 369-387. 
Collis, D. J. (1994). Research note: how valuable are organizational capabilities? Strategic Management Journal, 15, 143152. doi:10.1002/smj.4250150910.

Covin, J. G., \& Slevin, D. P. (1989). Strategic management of small firms in hostile and benign environments. Strategic Management Journal, 10(1), 75-87. doi:10.1002 /smj.4250100107.

Danneels, E. (2002). The dynamics of product innovation and firm competences. Strategic Management Journal, 23, 10951121. doi:10.1002/smj.275.

Day, G. S., \& Nedungadi, P. (1994). Managerial representations of competitive advantage. Journal of Marketing, 58(2), 31-44. doi: $10.2307 / 1252267$.

Diamantopoulos, A., \& Riefler, P. (2008). Formative Indikatoren: Einige Anmerkungen zu ihrer Art, Validität und Multikollinearität. Zeitschrift für Betriebswirtschaft, 78(11), 1183-1196. doi:10.1007/s11573-008-0099-7.

Dilman, D. (2000). Mail and internet surveys: the tailored design method. New York: Wiley.

Dosi, G., Nelson, R. R., \& Winter, S. G. (2002). The nature and dynamics of organizational capabilities. NY: Oxford University Press.

Drnevich, P. L., \& Kriauciunas, A. P. (2011). Clarifying the conditions and limits of the contributions of ordinary and dynamic capabilities to relative firm performance. Strategic Management Journal, 32(3), 254-279. doi:10.1002/smj.882.

Eisenhardt, K. M. (2013). Top management teams and the performance of entrepreneurial firms. Small Business Economics, 40(4), 805-816. doi:10.1007/s11187-013-9473-0.

EUR-Lex - 32003H0361 - EN, Commission Recommendation of 6 May 2003 concerning the definition of micro, small and medium-sized enterprises (Text with EEA relevance) (notified under document number C(2003) 1422), http://eur-lex. europa.eu/legal-content/EN/TXT/?uri=CELEX:32003 H0361. Accessed 18 October 2016.

Freel, M. S. (2005). Perceived environmental uncertainty and innovation in small firms. Small Business Economics, 25(1), 49-64. doi:10.1007/s11187-005-4257-9.

Garrett Jr., R. P., \& Holland, D. V. (2015). Environmental effects on the cognitions of corporate and independent entrepreneurs. Small Business Economics, 45(2), 369-381. doi:10.1007/s11187-015-9636-2.

Giudici, A., \& Reinmoeller, P. (2012). Dynamic capabilities in the dock: a case of reification? Strategic Organization, 10(4), 436-449. doi:10.1177/1476127012457977.

Goerzen, A. (2007). Alliance networks and firm performance: the impact of repeated partnerships. Strategic Management Journal, 28(5), 487-509. doi:10.1002/smj.588.

Grant, R. M. (1995). Contemporary strategy analysis: concepts, techniques, applications. 2nd edition. Cambridge.

Grant, R. M. (1996). Prospering in dynamically-competitive environments: organizational capability as knowledge integration. Organization Science, 7(4), 375-387. doi:10.1287/orsc.7.4.375.

Grant, R. M., \& Verona, G. (2015). What's holding back empirical research into organizational capabilities? Remedies for common problems. Strategic Organization, 13(1), 61-74. doi:10.1177/1476127014565988.

Gulati, R., \& Gargiulo, M. (1999). Where do interorganizational networks come from? American Journal of Sociology, 104(5), 1439-1493. doi:10.1086/210179.
Gulati, R., Nohria, N., \& Zaheer, A. (2000). Strategic networks. Strategic Management Journal, 21(3), 203-215. doi:10.1002 /(SICI)1097-0266(200003)21:3.

Hart, S. L. (1995). A natural-resource-based view of the firm. The Academy of Management Review, 20(4), 986-1014. doi: $10.2307 / 258963$.

Helfat, C. E., \& Raubitschek, R. S. (2000). Product sequencing: co-evolution of knowledge, capabilities and products. Strategic Management Journal, 21(10-11), 961-979.

Helfat, C., Finkelstein, S., Mitchell, W., Peteraf, M., Singh, H., Teece, D., \& Winter, S. (2007). Dynamic capabilities: understanding strategic change in organizations. Malden: Blackwell.

Hernández-Carrión, C., Camarero-Izquierdo, C., \& GutiérrezCillán, J. (2017). Entrepreneurs' social capital and the economic performance of small businesses: the moderating role of competitive intensity and entrepreneurs' experience. Strategic Entrepreneurship Journal, 11(1), 61-89. doi:10.1002/sej.1228.

Hine, D., Parker, R., Pregelj, L., \& Verreynne, M.-L. (2014). Deconstructing and reconstructing the capability hierarchy. Industrial and Corporate Change, 23(5), 1299-1325. doi:10.1093/icc/dtt046.

Homburg, C., \& Pflesser, C. (2000). A multiple-layer model of market-oriented organizational culture: measurement issues and performance outcomes. Journal of Marketing Research, 37(4), 449-462.

Homburg, C., Klarmann, M., \& Schmitt, J. (2010). Brand awareness in business markets: when is it related to firm performance? International Journal of Research in Marketing, 27(3), 201-212. doi:10.1016/j.ijresmar.2010.03.004.

Itami, H., \& Roehl, T. (1987). Mobilizing invisible assets. Cambridge: Harvard University Press.

Jacobides, M. G. (2006). The architecture and design of organizational capabilities. Industrial and Corporate Change, 15(1), 151-171. doi:10.1093/icc/dtj009.

Kale, P., Dyer, J. H., \& Singh, H. (2002). Alliance capability, stock market response, and long-term alliance success: the role of the alliance function. Strategic Management Journal, 23(8), 747-767. doi:10.1002/smj.248.

Keegan, A., \& Turner, J. R. (2002). The management of innovation in project-based firms. Long Range Planning, 35(4), 367-388. doi:10.1016/S0024-6301(02)00069-9.

Khandwalla, P. N. (1977). The design of organizations (Vol. 260). New York: Harcourt Brace Jovanovich.

Kumar, N., Stern, L. W., \& Anderson, J. C. (1993). Conducting interorganizational research using key informants. Academy of Management Journal, 36(6), 1633-1651. doi:10.2307/256824.

Lavie, D. (2006). The competitive advantage of interconnected firms: an extension of the resource-based view. The Academy of Management Review, 31(3), 638-658. doi:10.2307 120159233.

Lee, C., Lee, K., \& Pennings, J. M. (2001). Internal capabilities, external networks, and performance: a study on technologybased ventures. Strategic Management Journal, 22(6-7), 615-640. doi:10.1002/smj.181.

Leiblein, M. J. (2011). What do resource- and capability-based theories propose? Journal of Management, 37(4), 909-932. doi:10.1016/S0883-9026(03)00031-4.

Løwendahl, B. R. (2005). Professional service firms. Copenhagen: CBS Press. 
Løwendahl, B. R. (2014). 11 co-operative strategies for professional service firms: unique opportunities and challenges. Hoboken: Taylor and Francis.

Malone, T. W., \& Crowston, K. (1994). The interdisciplinary study of coordination. ACM Computing Surveys, 26(1), 87-119. doi:10.1145/174666.174668.

Man, T. W. Y., Lau, T., \& Chan, K. F. (2002). The competitiveness of small and medium enterprises: a conceptualization with focus on entrepreneurial competencies. Journal of Business Venturing, 17(2), 123-142. doi:10.1016/S0883-9026(00 )00058-6.

Matthews, C. H., \& Scott, S. G. (1995). Uncertainty and planning in small and entrepreneurial firms: an empirical assessment. Journal of Small Business Management, 33(4), 34-52.

Meiseberg, B., \& Ehrmann, T. (2012). Tendency to network of small and medium-sized enterprises: combining organizational economics and resource-based perspectives. Managerial and Decision Economics, 34(3-5), 283-300. doi: $10.1002 /$ mde. 2590 .

Miller, D., \& Dröge, C. (1986). Psychological and traditional determinants of structure. Administrative Science Quarterly, 31(4), 539-560. doi:10.2307/2392963.

Miller, D., \& Friesen, P. H. (1982). Innovation in conservative and entrepreneurial firms: two models of strategic momentum. Strategic Management Journal (pre-1986), 3(1), 1-25.

Miller, D., \& Friesen, P. H. (1983). Strategy-making and environment: the third link. Strategic Management Journal, 4(3), 221-235. doi:10.1002/smj.4250040304.

Mintzberg, H. (1973). Strategy-making in three modes. California Management Review, 16(2), 44-53. doi:10.2307/41164491.

Morgan, N. A., Kaleka, A., \& Katsikeas, C. S. (2004). Antecedents of export venture performance: a theoretical model and empirical assessment. Journal of Marketing, 68, 90-108. doi:10.1509/jmkg.68.1.90.24028.

Morgan, N. A., Slotegraaf, R. J., \& Vorhies, D. W. (2009). Linking marketing capabilities with profit growth. International Journal of Research in Marketing, 26(4), 284-293. doi:10.1016/j.ijresmar.2009.06.005.

Nelson, R. R. (1991). Why do firms differ, and how does it matter? Strategic Management Journal, 12, 61-74. doi:10.1002 /smj.4250121006.

Newbert, S. L. (2007). Empirical research on the resource-based view of the firm: an assessment and suggestions for future research. Strategic Management Journal, 28(2), 121-146. doi:10.1002/smj.573.

von Nordenflycht, A. (2010). What is a professional service firm? Toward a theory and taxonomy of knowledge-intensive firms. Academy of Management Review, 35(1), 155-174. doi:10.5465/AMR.2010.45577926.

Ostgaard, T. A., \& Birley, S. (1994). Personal networks and firm competitive strategy - a strategic or coincidental match? Journal of Business Venturing, 9(4), 281-305. doi:10.1016 /0883-9026(94)90009-4.

Podsakoff, P. M., MacKenzie, S. B., Lee, J.-Y., \& Podsakoff, N. P. (2003). Common method biases in behavioral research: a critical review of the literature and recommended remedies. Journal of Applied Psychology, 88(5), 879-903. doi:10.1037 /0021-9010.88.5.879.

Porter, M. E. (1985). Competitive advantage: creating and sustaining superior performance. New York: Free Press.
Porter, M. E. (1991). Towards a dynamic theory of strategy. Strategic Management Journal, 12, 95-117. doi:10.1002 /smj.4250121008.

Porter, M. E. (1998). Competing across locations: enhancing competitive advantage through a global strategy. Harvard Business School Press.

Powell, S. (2008). The management and consumption of organisational creativity. Journal of Consumer Marketing, 25(3), 158-166. doi:10.1108/07363760810870653.

Prahalad, C. K., \& Hamel, G. (1990). The core competence of the corporation. Harvard Business Review, 68(3), 79-90. doi:10.1007/3-540-30763-x_14.

Rauch, A., Wiklund, J., Lumpkin, G. T., \& Frese, M. (2009). Entrepreneurial orientation and business performance: an assessment of past research and suggestions for the future. Entrepreneurship Theory and Practice, 33(3), 761-787. doi:10.1111/j.1540-6520.2009.00308.x.

Sadler-Smith, E., Hampson, Y., Chaston, I., \& Badger, B. (2003). Managerial behavior, entrepreneurial style, and small firm performance. Journal of Small Business Management, 41(1), 47-67. doi:10.1111/1540-627X.00066.

Sanchez, R. (1995). Strategic flexibility in product competition. Strategic Management Journal, 16, 135-159. doi:10.2307 12486773.

Selznick, P. (1957). Leadership in administration: a sociological interpretation. Evanston: Row, Peterson.

Stabell, C. B., \& Fjeldstad, Ø. D. (1998). Configuring value for competitive advantage: on chains, shops, and networks. Strategic Management Journal, 19(5), 413-437. doi:10.1002/(SICI)1097-0266(199805)19:5.

Stumpf, S. A., Doh, J. P., \& Clark, K. D. (2002). Professional services firms in transition: challenges and opportunities for improving performance. Organizational Dynamics, 31(3), 259-279. doi:10.1016/S0090-2616(02)00113-4.

Teece, D. J. (2014). The foundations of enterprise performance: dynamic and ordinary capabilities in an (economic) theory of firms. The Academy of Management Perspectives, 28(4), 328-352. doi:10.5465/amp.2013.0116.

Teece, D. J., \& Pisano, G. (1994). The dynamic capabilities of firms: an introduction. Industrial and Corporate Change, 3(3), 537-556. doi:10.1093/icc/3.3.537-a.

Teece, D. J., Pisano, G., \& Shuen, A. (1997). Dynamic capabilities and strategic management. Strategic Management Journal, 18(7), 509-533. doi:10.1002/(SICI)1097-0266(199708)18:7.

Uzzi, B. (1996). The sources and consequences of embeddedness for the economic performance of organizations: the network effect. American Sociological Review, 61(4), 674-698. doi: $10.2307 / 2096399$.

Vorhies, D. W., \& Morgan, N. A. (2005). Benchmarking marketing capabilities for sustainable competitive advantage. Journal of Marketing, 69(1), 80-94. doi:10.2307/30162034.

Wade, M., \& Hulland, J. (2004). Review: the resource-based view and information systems research: review, extension and suggestions for future research. MIS Quarterly, 28(1), 107142. doi: $10.2307 / 25148626$.

Wales, W. J., Patel, P. C., Parida, V., \& Kreiser, P. M. (2013). Nonlinear effects of entrepreneurial orientation on small firm performance: the moderating role of resource orchestration capabilities. Strategic Entrepreneurship Journal, 7(2), 93121. doi: 10.1002/sej.1153. 
Windsperger, J. (2004). The dual network structure of franchising firms: property rights, resource scarcity and transaction cost explanations. In J. Windsperger, G. Cliquet, G. W. J. Hendrikse, \& M. Tuunanen (Eds.), Economics and management of franchising networks (pp. 69-88). Heidelberg: Physica.

Winter, S. G. (2003). Understanding dynamic capabilities. Strategic Management Journal, 24(10), 991-995. doi:10.1002/smj.318.
Zahra, S., Sapienza, H., \& Davidsson, P. (2006). Entrepreneurship and dynamic capabilities: a review, model and research agenda. Journal of Management Studies, 43, 917-955. doi:10.1111/j.1467-6486.2006.00616.x.

Zott, C., \& Amit, R. H. (2013). Crafting business architecture: the antecedents of business model design. Academy of Management Proceedings, 1. doi:10.5465/AMBPP.2013.15289abstract. 